\title{
PENERAPAN METODE PERMAINAN DENGAN MENGGUNAKAN MEDIA TUTUP BOTOL UNTUK MENINGKATKAN HASIL BELAJAR MATEMATIKA PESERTA DIDIK KELAS II MIS MIFTAHUL HUDA 1 PALANGKARAYA TAHUN PELAJARAN 2015/2016
}

\author{
Oleh \\ Sultan Muhamad Sidiq, Dedy Setyawan
}

\begin{abstract}
ABSTRAK
Penelitian ini bertujuan untuk mengetahui aktivitas dan peningkatan hasil belajar peserta didik dalam pembelajaran matematika dengan menerapkan metode permainan menggunakan media tutup botol di kelas II MIS Miftahul Huda 1 Palangka Raya.

Metode penelitian yang digunakan dalam penelitian ini adalah metode Penelitian Tindakan Kelas (PTK). Dengan jumlah subjek penelitian 35 orang peserta didik. Teknik pengumpulan data menggunakan teknik pengumpulan data kualitatif. Teknik analisis data didasarkan pada hasil siklus tiap proses pembelajaran di kelas II MIS Miftahul Huda 1 Palangka Raya.

Hasil penelitian menunjukan bahwa : (1). Aktivitas peserta didik menjadi lebih aktif pada saat pembelajaran Matematika dengan menerapkan metode permainan menggunakan media tutup botol. Pada siklus I skor rata-rata yang diperoleh peserta didik adalah 35,8 dengan kriteria baik, kemudian pada siklus II skor rata-rata yang diperoleh peserta didik meningkat menjadi 45,8 dengan kriteria sangat baik. (2).Ada peningkatan hasil belajar Matematika dengan menerapkan metode permainan menggunakan media tutup botol perkalian pada peserta didik kelas II MIS Miftahul Huda 1 Palangka Raya.Nilai rata-rata pada siklus I adalah 67,3 dengan ketuntasan klasikal 71,4\%, kemudian nilai rata-rata pada siklus II meningkat menjadi 85,3 dengan ketuntasan klasikal 94,3\%.
\end{abstract}

(C) Universitas Muhammadiyah Palangkaraya

\section{Kata kunci: Hasil Belajar, Metode Permainan, dan Media Tutup Botol Perkalian}

\section{PENDAHULUAN}

Belajar adalah salah satu tugas manusia di dunia ini dan melalui belajar manusia dapat meningkatkan kualitas hidupnya. Sama halnya dengan peserta didik dalam belajar akan lebih dan bermakna jika peserta didik mengalami apa yang di pelajarinya, bukan hanya sekedar mengenal dan mengetahuinya oleh karena itu proses belajar mengajar perlu di hubungkan dengan kejadian sehari-hari yang akrab dengan peserta didik. Salah satu usaha yang dilakukan guru untuk mencapai keberhasilan dalam suatu pembelajaran secara optimal yaitu dengan menerapkan metode permainan karena metode permainan dapat melatih dan 
mengembangkan imajinasi dan kecerdasan peserta didik.

Pada umumnya peserta didik yang duduk di kelas rendah seperti kelas II SD cenderung memiliki keingintahuan yang besar, senang berbicara dan selalu kreatif oleh karena itu metode permainan dan penggunaan media yang tepat dan menarik sangat penting dipergunakan oleh guru khususnya dalam pelajaran matematika. Pelajaran matematika adalah pelajaran yang membentuk pola pikir peserta didik agar dapat berpikir logis, kritis, cermat, kreatif dan mengembangkan nalar berfikirnya. Belajar matematika diperlukan keseriusan dan penalaran yang tinggi.

Hasil observasi yang dilakukan oleh peneliti di MIS Miftahul Huda 1 khususnya pada peserta didik kelas II MIS Miftahul Huda 1, peserta didik mengalami kesulitan dalam operasi hitung perkalian yang hasilnya dua bilangan, guru melaksanakan pembelajaran kurang sesuai dengan SK dan KD,yaitu kurang bervariasi dalam menerapkan metode pembelajaran dan menggunakan media dalam pembelajaran matematika pembelajaran serta lebih berpusat pada guru.

Hal ini berdampak kepada hasil belajar peserta didik pada mata pelajaran matematika yang masih di bawah standar ketuntasan belajar. Peneliti melihat dari hasil nilai kelas II yang berjumlah 35 peserta didik hanya $40 \%$ kelas II yang mampu mencapai standar ketuntasan yaitu 14 peserta didik dan $60 \%$ yang masih di bawah standar ketuntasan minimal KKM untuk
SK dan KD yaitu 21 peserta didik, nilai yang ditetapkan dari sekolah yaitu 60 .

Pada permasalahan di atas, kegiatan peserta didik harus lebih aktif dan menyenangkan khususnya pada pelajaran matematika. guru seharusnya menggunakan strategi pembelajaran yaitu menggunakan beberapa metode pembelajaran yang sesuai dan menggunakan media pembelajaran yang menarik sehingga pembelajaran matematika menjadi lebih mudah bagi peserta didik khususnya yang duduk di kelas II sekolah dasar. Pembelajaran tidak hanya berpusat pada guru saja melainkan keaktifan peserta didik dalam pembelajaran. salah satu metode yang digunakan adalah metode permainan.

Seperti yang sudah disinggumg di atas, metode permainan menurut Piaget (Yuliani Nurani, 2013:42) mengatakan bahwa "permainan adalah suatu kegiatan yang dilakukan berulamgulang dan menimbulkan kesenangan / kepuasan bagi diri seseorang". Sedangkan menurut Parten (Yuliani Nurani, 2013:42) mengatakan bahwa "permainan merupakan kebutuhan bagi anak karena melaui permainan anak akan memperoleh pengetahuan yang dapat mengembangkan kemampuan dirinya".

Berdasarkan pendapat di atas dapat disimpulkan bahwa metode permainan adalah suatu cara penyajian bahan pelajaran melalui berbagai permainan. Permainan yang ditawarkan adalah berupa simulasi yang dapat dibuat oleh guru.

Selain metode yang digunakan, guru dapat menggunakan media sebagai penyampai pesan pembelajaran yang 
dapat berupa benda - benda yang sering di jumpai di lingkungan sekitar. Salah satu nya adalah tutup botol. Tutup botol dapat dijadikan sebagai media pembelajaran khususnya dalam mata pelajaran matematika pada materi perkalian.

Menurut Sufani Prabowo dan Puji Rahayu (2006:55) mengatakan bahwa "Tutup botol perkalian merupakan perantara yang membantu memperjelas materi pelajaran tutup botol perkalian juga dipercaya dapat membantu guru dalam mempermudah serta mengatasi masalah komunikasi yang dialami oleh guru ketika mengajarkan suatu materi. Meskipun demikian tentu posisi dan peran guru di kelas tidak dapat digantikan oleh media tutup botol perkalian karena media berupa alat bantu yang memfasilitasi guru dalam pembelajaran".

Berdasarkan definisi di atas dapat disimpulkan bahwa media tutup botol perkalian merupakan alat bantu dalam proses pembelajaran matematika yang berfungsi untuk mempermudah peserta didik dalam memahami materi tentang perkalian. Media tutup botol perkalian termasuk ke dalam jenis media sederhana, karena media ini mudah diperoleh dan cara penggunaannya tidak sulit.

\section{METODE PENELITIAN}

Jenis penilitian yang digunakan dalam penelitian ini adalah penelitian kualitatif dengan pendekatan Penelitian Tindakan Kelas. Arifin (2012:3) berpendapat bahwa :

"Penelitian Tindakan Kelas (PTK) dapat diartikan sebagai suau proses penyelidikan ilmiah dalam bentuk refleksi diri yang melibatkan guru dalam situasi pendidikan tertentu dengan tujuan memperbaiki pemahaman dan keadilan tentang situasi atau praktik pendidikan, memahami tentang praktik itu dilaksanakan."

Kehadiran dan peran peneliti adalah sebagai orang yang menyadari adanya permasalahan dalam proses belajar mengajar di kelas. Pada penelitian ini peneliti bekerjasama dengan pihak lain, peneliti akan bekerjasama dengan guru kelas II selaku pihak lain yang dijadikan sebagai partner oleh peneliti dan teman sejawat. Peneliti berperan sebagai pengajar atau pelaksana tindakan kelas, sedangkan guru kelas II berperan sebagai pengamat atau observer. Hal ini dilakukan untuk mendukung objektivitas hasil penelitian tindakan kelas yang dilakukan oleh peneliti.

Dalam pelaksanaan penelitian tindakan kela sini yang menjadi subjek penelitian adalah peserta didik kelas II MIS Miftahul Huda 1 yang berjumlah 35 orang. Terdiri dari 20 peserta didik perempuan dan 15 peserta didik lakilaki. Sedangkan yang menjadi objek penelitian adalah hasil belajar matematika. Pengumpulan data yang diperoleh pada penelitian ini dilakukan melalui pengamatan (observasi) dan tes hasil belajar.

Data yang dikumpulkan dari setiap kegiatan yang dilaksanakan dalam siklus PTK dianalisis secara deskriptif dengan menggunakan teknik persentase untuk melihat kecenderungan yang terjadi dalam pembelajaran. Data yang diperoleh 
melalui instrumen yang telah dikumpulkan sebelumnya diolah menjadi dua jenis yaitu kualitatif dan kuantitatif.

Data kualitatif diperoleh dari aktivitas terhadap peneliti dan aktivitas terhadap peserta didik dan respon peserta didik selama proses belajar rmengajar dengan menganalisis hasil belajar yang dilihat dalam proses belajar mengajar dengan metode permainan menggunakan media tutup botol. Data kuantitatif berasal dari hasil tes yang diberikan pada setiap akhir siklus kegiatan. Hal ini dilakukan untuk mengetahui peningkatan hasil belajar peserta didik pada pendekatan yang diterapkan.

\section{HASIL DAN PEMBAHASAN}

Data dari hasil penelitian ini berupa: 1) pengamatan aktivitas guru dan peserta didik, 2) hasil belajar matematika dengan metode permainan menggunakan media tutup botol.

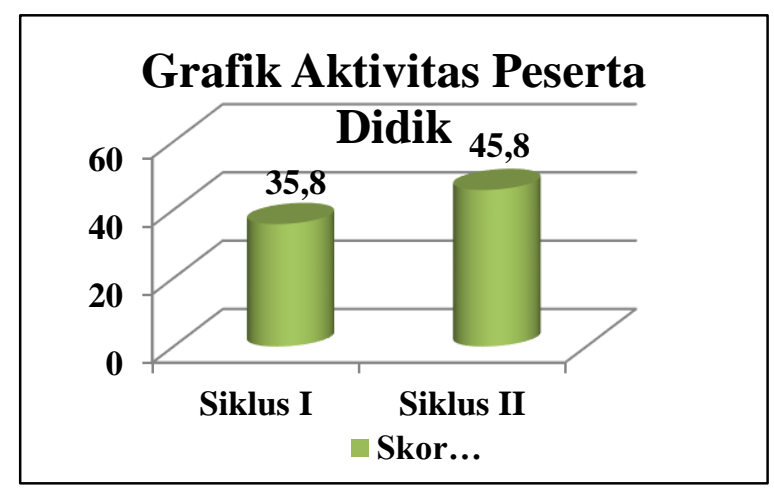

Gambar 1

Grafik Aktivitas Peserta Didik

Berdasarkan analisis data yang dilakukan terhadap aktivitas belajar peserta didik maka dapat diperoleh hasil aktivitas peserta didik pada setiap siklusnya. Pada Siklus I, aktivitas peserta didik memperoleh skor rata-rata 35,8 dengan kriteria baik. Pada Siklus II aktivitas peserta didik memperoleh skor rata-rata 45,8 dengan kriteria sangat baik. Hal ini menunjukkan bahwa peserta didik lebih aktif pada saat pembelajaran Matematika dengan menerapkan metode permainan dengan menggunakan media tutup botol perkalian.

\section{1) Hasil belajar matematika peserta didik dengan metode permainan menggunakan media tutup botol. Grafik Persentase} Ketuntasan Belajar Klasikal

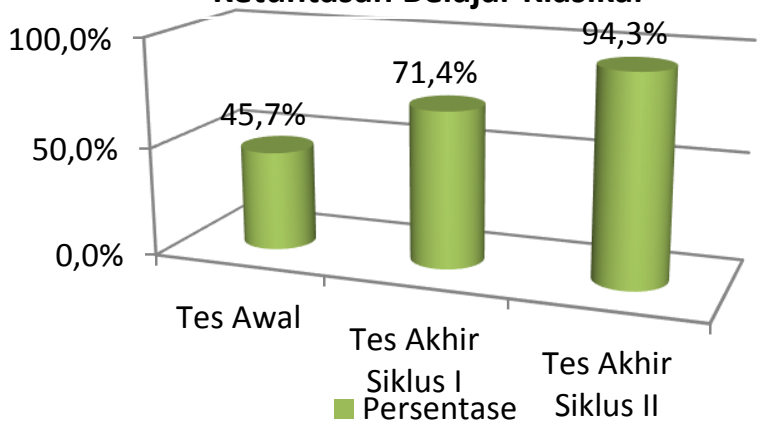

Gambar 2

Grafik Persentase Ketuntasan Belajar Klasikal

Berdasarkan analisis data yang dilakukan terhadap hasil belajar peserta didik, maka dapat diperoleh hasil belajar peserta didik dari tes awal, tes akhir Siklus I dan tes akhir Siklus II. Pada tes awal, hasil belajar peserta didik memperoleh nilai rata-rata 55,2 (dibawah $\mathrm{KKM} \geq 60$ ) dengan ketuntasan klasikal 45,7\% dengan kriteria kurang tercapai. Pada Siklus I hasil belajar peserta didik memperoleh nilai rata-rata 67,3 dengan ketuntasan klasikal 71,4\% dengan kriteria cukup tercapai. Pada 
Siklus II hasil belajar peserta didik memperoleh nilai rata-rata 85,3 dengan ketuntasan klasikal 94,3\% dengan kriteria sangat tercapai.

\section{KESIMPULAN}

Berdasarkan hasil penelitian, maka dapat disimpulkan beberapa hal sebagai berikut:

1. Aktivitas peserta didikberdasarkan analisis data yang dilakukan terhadap aktivitas belajar peserta didik maka dapat diperoleh hasil aktivitas peserta didik pada setiap siklusnya. Pada Siklus I, aktivitas peserta didik memperoleh skor ratarata 35,8 dengan kriteria baik. Pada Siklus II aktivitas peserta didik memperoleh skor rata-rata 45,8 dengan kriteria sangat baik. Hal ini menunjukkan bahwa peserta didik lebih aktif pada saat pembelajaran Matematika dengan menerapkan metode permainan dengan menggunakan media tutup botol.

2. Hasil belajar peserta didikberdasarkan analisis data yang dilakukan terhadap hasil belajar peserta didik, maka dapat diperoleh hasil belajar peserta didik dari tes awal, tes akhir Siklus I dan tes akhir Siklus II. Pada tes awal, hasil belajar peserta didik memperoleh nilai rata-rata 55,2 (dibawah $\mathrm{KKM}$ 260) dengan ketuntasan klasikal $45,7 \%$ dengan kriteria kurang tercapai. Pada Siklus I hasil belajar peserta didik memperoleh nilai rata-rata 67,3 dengan ketuntasan klasikal $71,4 \%$ dengan kriteria cukup tercapai. Pada Siklus II hasil belajar peserta didik memperoleh nilai rata-rata 85,3 dengan ketuntasan klasikal 94,3\% dengan kriteria sangat tercapai.

\section{DAFTAR PUSTAKA}

Arifin, Zainal. 2012. Penelitian Pendidikan Metode dan Paradigma Baru. Bandung : PT Remaja Rosdakarya.

Prabowo, S, dan Puji Rahayu. 2006. Pengelolaan Kelas. Bandung: UPI Press.

Yuliani, Nurani. 2013. Bermain Kreatif Berbasis Kecerdasan Jamak. Bandung : Indeks. 